\title{
Pattern of Renal Cell Carcinoma - A Single Center Experience in Nepal.
}

\author{
Sidharth, Luitel BR, Gupta DK, Maskey P, Chalise PR, Sharma UK, Gyawali PR, \\ Shrestha GK, Sayami G, Joshi BR
}

\author{
Urology Unit \\ Department of Surgery \\ Tribhuwan University Teaching Hospital \\ Maharajgunj, Kathmandu, Nepal.
}

Corresponding Author

Sidharth

Urology Unit

Department of Surgery

Tribhuwan University Teaching Hospital

Maharajgunj, Kathmandu, Nepal.

Email: sidd_iom@yahoo.com

\section{Citation}

Sidharth, Luitel BR, Gupta DK, Maskey P, Chalise PR, Sharma UK, Gyawali PR, Shrestha GK, Sayami G, Joshi BR. Pattern ofRenal Cell Carcinoma - A Single Center Experience in Nepal. Kathmandu Univ Med $J$ 2011;35(3):185-8.

\begin{abstract}
Background

Renal tumor is the 13th most common malignancy in the world and more than $90 \%$ of renal tumors are renal cell carcinomas. As there is no data available on renal cell carcinoma in Nepal, hence this study was undertaken to analyze the patterns of renal cell carcinoma in patients with renal mass at a tertiary level hospital in Nepal.
\end{abstract}

\section{Objectives}

To analyze the patterns of renal cell carcinoma in patients with renal mass at a tertiary level hospital in Nepal.

\section{Methods}

The case records of 50 consecutive patients with renal cell carcinoma presenting at the Tribhuvan University Teaching Hospital, Kathmandu from July 2006 to June 2011 were retrospectively evaluated for presenting symptoms, physical finding, investigation and histopathology report.

\section{Results}

Out of 50 patients, $64 \%$ were male and $36 \%$ were female. The age ranged between 11 to 78 years (mean \pm SD: $55 \pm 15$ years). Fifty four percent of patients were smokers. Incidentally tumor was detected in $40 \%$ cases by ultrasonography and the typical triad was present in only $4 \%$. The tumor was occupying upper pole in $40 \%$ of cases. The tumor size ranged from 3 to $15 \mathrm{~cm}$ (mean \pm SD: $7.3 \pm 2.9 \mathrm{~cm}$ ). Histopathologically, $76 \%$ of the patient had organ confined renal cell carcinoma (T12 NO MO). Clear cell was the most common type seen in $86 \%$. Fuhrman's nuclear grade 2 was found in $50 \%$.

\section{Conclusion}

Many of the renal cell carcinoma are detected incidentally, at an early stage and are of clear cell subtype.

\section{KEY WORDS}

Incidental renal tumor, Nepal, Renal cell carcinoma.

\section{INTRODUCTION}

Worldwide, renal tumor is the 13th most common malignancy. ${ }^{1}$ More than $90 \%$ of renal tumors are renal cell carcinomas (RCC) and the incidence continues to increase. ${ }^{2,3}$ Cigarette smoking is considered to be the most common cause while many other causes have also been reported. ${ }^{4,5}$ The commonest age at presentation ranges from 60-70 years and is more common in males than in females. ${ }^{6-8}$ The most frequent presentation is haematuria followed by flank pain and a palpable mass on clinical examination. ${ }^{9}$ The classical triad of symptoms are present in only limited number of cases. Majority of the lesions are now detected incidentally by an ultrasonography with high resolution probes. ${ }^{10-12}$ So the dictum in recent years is that any solid mass in the kidney on ultrasonography should be considered as malignant until proven otherwise. Radiotherapy, chemotherapy, immunotherapy and tyrosine kinase inhibitors have all been used for patients with metastatic disease but their curative role has to be proven by larger randomized control trials. ${ }^{13}$ Despite the innovations in the management of RCC in recent years, mortality rates have continued to rise. ${ }^{3,14}$ As there is no data available on RCC in Nepal, hence this study was undertaken 
to analyze the patterns of RCC at a tertiary level hospital in Nepal highlighting the patients demography, clinical presentation, diagnostic evaluation and pathological finding.

\section{METHODS}

This was a retrospective study done in the Urology unit, Department of Surgery at Tribhuvan University Teaching Hospital, Kathmandu, Nepal from July 2006 to June 2011. The medical records of 50 consecutive patients with histopathologically confirmed primary RCC were reviewed.

The individual patient factors like age, gender, smoking, symptoms, tumor location, size, TNM staging and histopathology reports were retrieved for analysis. The seventh edition of the American Joint Committee on Cancer TNM staging system was used to classify cancer stage and tumor spread. ${ }^{15}$

\section{RESULTS}

A total of 50 patients were diagnosed to have RCC in the past 5 years. The male to female ratio was 1.7:1. The age ranged between 11-78 years (mean \pm SD: $55 \pm 15$ years) and $86 \%$ were aged more than 40 years. Fifty four percent of the patients were smokers. (Table 1 )

Renal cell carcinoma was incidentally diagnosed by ultrasonography in $40 \%$ cases and rest $60 \%$ was symptomatic. The classical triad of flank pain, gross hematuria, and palpable abdominal mass was present in only two patients. Mean duration of symptom was 3.5 (0 24) months. (Table 1)

Table 1. Characterization of patients $(n=50)$.

\begin{tabular}{|l|l|}
\hline Characteristics & No. of patients (\%) \\
\hline Age (in years) & $7(14)$ \\
\hline$<40$ & $23(46)$ \\
\hline $40-60$ & $20(40)$ \\
\hline$>60$ & \\
\hline Gender & $32(54)$ \\
\hline Male & $18(36)$ \\
\hline Female & \\
\hline Smoking & $27(54)$ \\
\hline Smoker & $23(46)$ \\
\hline Non Smoker & \\
\hline Symptoms & $20(40)$ \\
\hline Incidental & $14(28)$ \\
\hline Pain & $8(16)$ \\
\hline Hematuria & $2(4)$ \\
\hline Pain and mass & $4(8)$ \\
\hline Pain and hematuria & $2(4)$ \\
\hline Triad & \\
\hline
\end{tabular}

Table 2. Characterization of the tumors $(n=50)$.

\begin{tabular}{|l|l|}
\hline Characteristics & No. of patients (\%) \\
\hline Laterality & \\
\hline Right & $26(52)$ \\
\hline Left & $23(46)$ \\
\hline Bilateral & $1(2)$ \\
\hline Tumor Location (Pole) & \\
\hline Upper & $20(40)$ \\
\hline Mid & $9(18)$ \\
\hline Lower & $5(10)$ \\
\hline Upper mid & $7(14)$ \\
\hline Mid lower & $7(14)$ \\
\hline Complete & $2(4)$ \\
\hline Size (in cms) & \\
\hline$\leq 4$ & $8(16)$ \\
\hline 4.1 - 7 & $21(42)$ \\
\hline 7.1 - 10 & $14(28)$ \\
\hline$>10$ & $7(14)$ \\
\hline Operation & \\
\hline Radical Nephrectomy (RN) & $31(62)$ \\
\hline RN with Lymphadenectomy & $13(26)$ \\
\hline RN with IVC Thrombectomy & $3(6)$ \\
\hline Not operated & $3(6)$ \\
\hline
\end{tabular}

One case had bilateral RCC with positive family history of renal malignancy and was diagnosed to have von Hipple Lindau disease. The tumor was occupying upper pole in $40 \%$ of cases. On CT scan, $42 \%$ of the patient had tumor size of more than $7 \mathrm{~cm}$, with the mean size of $7.3 \pm 2.9 \mathrm{~cm}$ (range: $3-15 \mathrm{~cm}$ ). Three patients had Nevus level-II infrahepatic inferior vena cava (IVC) thrombus extension and underwent IVC thrombectomy along with Radical Nephrectomy (RN). Three patients were not operated for advanced RCC, out of which one patient had bilateral RCC with von Hipple Lindau disease and refused further treatment. Other two patients had Nevus level-IV suprahepatic IVC thrombus, one of them succumbed due to tumor lysis syndrome and the other patient refused to undergo surgery. In all the above three cases diagnosis of RCC was confirmed by fine needle aspiration cytology. (Table 2)

Histopathologically, $86 \%$ of the patients had clear cell type of RCC, with Fuhrman Grade 2 being the most common. Eighty-four percent of the patients had tumor confined to the kidney i.e. T1-2 stage. (Table 3)

Only forty (80\%) patients were on regular follow up (range: 6-66 months), out of which 37 (92.5\%) has recurrence free survival and 3 (7.5\%) patients had RCC related mortality.

\section{DISCUSSION}

The peak incidence of RCC in this study was in the fourth and fifth decades of life, in contrast to other studies in the 
Table 3. Histopathologic features $(n=50)$.

\begin{tabular}{|c|c|}
\hline Characteristics & No. of patients (\%) \\
\hline \multicolumn{2}{|l|}{ Type } \\
\hline Clear cell & $41(82)$ \\
\hline Multilocular Cystic Clear cell & $2(4)$ \\
\hline Papillary & $7(14)$ \\
\hline \multicolumn{2}{|l|}{ Fuhrmans Grade } \\
\hline 1 & $7(14)$ \\
\hline 2 & $25(50)$ \\
\hline 3 & $14(28)$ \\
\hline 4 & $4(8)$ \\
\hline \multicolumn{2}{|l|}{ Necrosis } \\
\hline Present & $20(40)$ \\
\hline Absent & $30(60)$ \\
\hline \multicolumn{2}{|l|}{ Sarcomatoid Changes } \\
\hline Present & $8(16)$ \\
\hline Absent & $42(84)$ \\
\hline \multicolumn{2}{|l|}{ T Stage } \\
\hline $1 \mathrm{a}$ & $6(12)$ \\
\hline $1 b$ & $20(40)$ \\
\hline $2 a$ & $11(22)$ \\
\hline $2 b$ & $5(10)$ \\
\hline $3 a$ & $2(4)$ \\
\hline $3 b$ & $3(6)$ \\
\hline $3 c$ & $2(4)$ \\
\hline 4 & $1(2)$ \\
\hline \multicolumn{2}{|l|}{ N Stage } \\
\hline 0 & $45(90)$ \\
\hline 1 & $5(10)$ \\
\hline \multicolumn{2}{|l|}{ M Stage } \\
\hline 0 & $47(94)$ \\
\hline 1 & $3(6)$ \\
\hline \multicolumn{2}{|l|}{ Tumor spread } \\
\hline Organ confined (T1-2 NO M0) & $38(76)$ \\
\hline Locally advanced (T3-4 NO MO) & $6(12)$ \\
\hline Metastatic (Tany N+ MO or Tany NO M+) & $6(12)$ \\
\hline
\end{tabular}

western world, where the majority of cases were in their sixth and seventh decades. This could be because of the wide application of ultrasonography as screening tests in older age and prolonged life expectancy. Patard et al also reported an increase in the mean age at diagnosis from 63 years in 1984 - 1992 to 65 years in $1998-2003 .{ }^{16}$ In our study, the mean age at diagnosis was 55 years which is similar to the finding of choi et al and Pradhan et al. ${ }^{17,18}$

The incidence of incidental RCC ranged from 15 to $61 \%$ and recently reported to be as high as $72.7 \%$ from South korea. ${ }^{17,19}$ Such a wide range of incidence in the literature could be related to differences in definition of incidental detection in various studies, as well as the referral pattern and health screening policies of different countries. Apparently, most of the major series included asymptomatic patients and patients with non-specific symptoms into the incidental detection group. Using same criteria, the present series showed an incidence of $40 \%$ which is similar to the finding of Siow WY et al. ${ }^{19}$ All cases of incidental RCC was detected by ultrasonography in our study. As we found that in Nepalese population RCC occurred more in middle aged patients and has incidental detection. Therefore, liberal use of ultrasound abdomen will definitely help in early detection of the tumor.

Varicocele is often a late sign of RCC, carrying a very poor prognosis. ${ }^{20}$ In the present study left side varicocele was found in only one (2\%) patient having metastatic RCC with Nevus level II IVC thrombus.

The controversy of radical versus partial nephrectomy continues and the later treatment option is supported by the fact that $50 \%$ of the tumors are situated at either pole in our series. Prevalence of metastasis is reportedly higher, while cancer specific and disease free survival is lower with increasing size of tumor at presentation. ${ }^{21}$ In our study, $86 \%$ had tumor size $>4 \mathrm{~cm}$ with mean of $7.3 \pm 2.9 \mathrm{~cm}$ and as frozen section facilities are not available in our center. Hence that limits our partial or nephron sparing surgery and justifies radical nephrectomy.

Histologically, the highest proportion of tumors was of the clear cell type (86\%) and other was papillary subtype. Indian study by Pradhan et al also showed clear cell RCC to be the most common adult renal tumor in $74.8 \%$ cases. ${ }^{18}$ Other subtypes like chromophobe and collecting duct were not detected in our series; it may be due to small case series. Fuhrman nuclear grade 2 is the most common which is similar to other studies. ${ }^{16,18,19}$

As our study was retrospective and a single-center experience, there were limitations in representing all aspects of RCC. It would be too early to state the different modes of presentation and pathological sub types. In future, multicentric study is needed to analyze the characteristics of RCC in Nepal.

\section{CONCLUSION}

Many of the renal cell carcinoma are detected incidentally, at an early stage and are of clear cell subtype. The age of presentation is one decade earlier than western population.

\section{REFERENCES}

1. Ferlay J, Shin HR, Bray F, et al. Estimates of worldwide burden of cancer in 2008: GLOBOCAN 2008. Int J Cancer 2010;15:2893-917.

2. Jemal A, Siegel R, Ward E, et al. Cancer statistics 2007. CA Cancer J Clin 2007;57:43-66.

3. Sun $\mathrm{M}$, Thuret $\mathrm{R}$, Abdollah $\mathrm{F}$, et al. Age-adjusted incidence, mortality, and survival rates of stage-specific renal cell carcinoma in North America: a trend analysis. Eur Urol 2011;59:135-41.

4. Hu J, Ugnat AM. Active and passive smoking and risk of renal cell carcinoma in Canada. Eur J Cancer 2005;41:770-8. 
5. Hunt JD, Vander OL, McMillan GP, et al. Renal cell carcinoma in relation to cigarette smoking: meta-analysis of 24 studies. Int J Cancer 2005;114:101-8.

6. Ferlay $\mathrm{J}$, Autier $\mathrm{P}$, Boniol $\mathrm{M}$, et al. Estimates of the cancer incidence and mortality in Europe in 2006. Ann Oncol 2007;18:581-92.

7. Jemal A, Siegel R, Ward E, et al. Cancer statistics 2006. CA Cancer J Clin 2006;56:106-30.

8. Ljungberg B, Hanbury DC, Kuczyk MA, et al. Renal cell carcinoma guideline. Eur Urol 2007;51:1502-10.

9. Gibbons RP, Monte JE, Correa RJ Jr, et al. Manifestations of renal cell carcinoma. Urology 1976;8:201-6.

10. Chow WH, Devesa SS, Waren JL, et al. Rising incidence of renal cell carcinoma in the United States. JAMA 1999;281:1628-31.

11. Hock LM, Lynch J, Balaji KC. Increasing incidence of all stages of kidney cancer in the last 2 decades in the United States: an analysis of surveillance, epidemiology and end results program data. J Urol 2002;167:57-60.

12. Jayson $M$, Sanders $H$. Increased incidence of serendipitously discovered renal cell carcinoma. Urology 1998;51:203-5.

13. Escudier B, Eisen T, Stadler WM, et al. Sorafenib in advanced clear-cell renal-cell carcinoma. N Engl J Med 2007;356:125-34.

14. Hollingsworth JM, Miller DC, Daignault S, et al. Rising incidence of small renal masses: a need to reassess treatment effect. J Nat/ Cancer
Inst 2006;98:1331-4.

15. Edge SB, Byrd DR, Compton CC, et al. editors. AJCC cancer staging manual (7th ed). New York, NY: Springer; 2010.

16. Petard JJ, Tazi $\mathrm{H}$, Bensalah $\mathrm{K}$, et al. The changing evolution of renal tumours: a single center experience over a two-decade period. Eur Urol 2004 Apr;45(4):490-3.

17. Choi JB, Yoon B, Kim SJ, et al. Changes in clinicopathological characteristics of Renal cell carcinoma in the past 25 years: A singlecenter experience. Korean J Urol 2011;52:110-4.

18. Pradhan D, Kakkar N, Bal A, et al. Sub-typing of renal cell tumours; Contribution of ancillary techniques. Diagnostic Pathology 2009;4(1): 21

19. Siow WY, Yip SKH, Ng LG, et al. Renal cell carcinoma: incidental detection and pathological staging. J $R$ Coll Surg Edinb 2000 Oct;45(5):291-5.

20. Ou YC, Yang CR, Ho HC, et al. The symptoms of renal cell carcinoma related to patients' survival. J Chin Med Assoc 2003;66:537-43.

21. Mike MN, Inderbir SG. Effect of renal cancer size on the prevalence of metastasis at diagnosis and mortality. J Urol 2009;181:1020-7. 